Techniques \& Culture

5 | 1985

Par où passe la technologie I

\title{
Les origines de la technologie
}

\section{Alfred Espinas}

\section{OpenEdition}

Journals

Édition électronique

URL : https://journals.openedition.org/tc/965

DOI : $10.4000 /$ tc. 965

ISSN : 1952-420X

\section{Éditeur}

Éditions de l'EHESS

\section{Édition imprimée}

Date de publication : 1 juin 1985

ISSN : 0248-6016

\section{Référence électronique}

Alfred Espinas, « Les origines de la technologie», Techniques \& Culture [En ligne], 5 | 1985, mis en ligne le 25 janvier 2006, consulté le 29 septembre 2022. URL : http://journals.openedition.org/tc/965 ; DOI : https://doi.org/10.4000/tc.965

Ce document a été généré automatiquement le 29 septembre 2022.

Tous droits réservés 


\section{Les origines de la technologie}

Alfred Espinas 